Article

\title{
Forest Management Certification in Romania: Motivations and Perceptions
}

\author{
Aureliu Florin Halalisan ${ }^{1, *(1)}$, Ioan Vasile Abrudan ${ }^{2}$ and Bogdan Popa ${ }^{1}$ \\ 1 Department of Forest Engineering, Faculty of Silviculture and Forest Engineering, Transilvania University of \\ Brasov, Sirul Beethowen street, no. 1, 500123 Brasov, Romania; popab03@gmail.com \\ 2 Department of Silviculture, Faculty of Silviculture and Forest Engineering, Transilvania University of Brasov, \\ Sirul Beethowen street, no. 1, 500123 Brasov, Romania; abrudan@unitbv.ro \\ * Correspondence: aureliu.halalisan@unitbv.ro; Tel.: +04-0752099328
}

Received: 31 May 2018; Accepted: 13 July 2018; Published: 15 July 2018

\begin{abstract}
Forestland privatization and transition to a market economy triggered important changes in the Romanian forest sector, imposing challenges for forest management structures. Voluntary forest management certification has been considered a possible solution; therefore, the certified forest area has increased rapidly regardless of the land owner. The purpose of this study is to provide an insight into the certification process. It presents the result of a survey applied to 417 forest management structures in Romania, which was intended to identify the perception of their managers regarding the reasons to adopt certification, the changes determined by the certification, the problems during the process, and the benefits. The study reveals the difference in perception among different types of forest management structures. Non-state management structures voluntarily adopted FSC certification, mainly aiming to obtain economic advantages. Most of the respondents indicated important changes in the consultation with stakeholders including local communities, transparency and clear records, the use of chemicals, and biodiversity protection. Although the FSC certification was not perceived as solving issues like illegal logging, there is a general perception that it improved forest management. The study concludes that the FSC certification proves the willingness of the Romanian forest management sector to cope with the market and trends and clarify its position in society.
\end{abstract}

Keywords: forest certification; management; sustainability; Romania

\section{Introduction}

In the last decades, a significant number of regulating systems and tools have been developed that aim to address the increasing interest in promoting sustainable forest management $[1,2]$. Amongst them, forest management certification is considered a useful tool that integrates economic, ecological, and social aspects of taking care of forests. Since the beginning of forest certification, civil society has played an important role in promoting and developing this tool, starting from addressing the issue of illegal logging in tropical zones or organizing numerous campaigns for boycotting tropical wood commerce [3,4]. There are many recognized forest certification schemes, with some of them being deployed globally, including the Forest Stewardship Council (FSC) and Program for the Endorsement of Forest Certification (PEFC), and some used at a national level, such as the Indonesian Ecolabelling Institute and Indonesian Forestry Certification Cooperation (IFCC) in Indonesia, the China Forest Certification Council (CFCC) in China, the Japanese Sustainable Green Ecosystem Council (SGEC) etc. Choosing a forest certification scheme over others is influenced by different factors, such as: organization type, country specificity, costs, ownership etc. [5]. The FSC standard for certifying forest management is based on the principles established in 1994 (Principles from 1 to 9) and in 1996 (Principle 10), having global applicability for all types of forests. The 10 principles and 56 criteria 
of the FSC standard cover economic, social, and environmental aspects of forest management [6]. FSC principles award, for already confirmed reasons, a major importance to social aspects: the second principle (Workers' Rights and Employment Conditions), the third principle (Indigenous Peoples' Rights-partially applicable in Romania), and the fourth principle (Community Relations) are important requirements for enforcing employees' rights and facilities for forest dependent communities. In the FSC scheme, the forest management evaluation process is conducted by an independent party (certification bodies), aiming to achieve an increased credibility and transparency of the process [7]. It consists of verifying every indicator of the FSC standard. Forest management organizations or forest owners can address the identified non-conformities by applying proper corrective actions to achieve improvements in conformity with the FSC standard. During the main evaluation, all the criteria of the FSC standards are assessed, the non-conformities are revised, and the previously identified non-conformities are addressed. Besides making observations on daily field and desk activities of the forest management organization, the evaluation process also includes interviews and consultations with managers, employees, and local communities or other stakeholders that can be affected by the certification of that particular forest management organization [8]. The FSC certification scheme has evolved and developed over time. Although it was initially designed to address tropical illegal wood commerce, it has grown and spread all over the world, and has become an effective market tool in many countries and regions, including Europe. In April 2018, 199.27 million ha in 85 countries were certified under the FSC scheme, with 33,759 certificates issued to companies for FSC certified products traceability [9].

The Romanian forest sector has been affected by significant changes during the last decades. Immediately after the fall of the communist regime in 1989, forest management was done by the state for all Romanian forests, through 360 state forest districts (FD). Since 2002, the forestland restitution process has triggered institutional and regulation changes that enabled the creation and development of non-state FDs_-forest management structures for non-state forests [10]. According to the Romanian Forest Act [11], all non-state forest owners in Romania must sign management contracts for their forest with an authorized FD, having the possibility to choose between state or non-state FDs. All FDs (state or non-state) are equal in the face of the law in terms of rights and obligations and they must pass a permitting process conducted by the central authority for forestry to be able to operate. By the end of the forestland restitution, in 2011, almost 3.35 million ha were returned to former owners (out of the total surface of Romanian forests of 6.65 million ha), and almost half of this surface was already managed by non-state FDs [12]. At that time, 132 private FDs were managing 1.5 million ha of forestland [12], while the state FDs, grouped under the umbrella of the National Forest Administration-Romsilva (NFA), were managing all the state-owned forests and a part of the non-state forests. All these changes in ownership and management structures represented challenges for both state and non-state FDs [13]. Communication between stakeholders [14], the absence of a performant management for small forest owners, fragmentation of property, and changes in forest specific legislation and the institutional frame to adapt to the new economic and social realities are only some of the issues faced by both private and state forest management in Romania [13].

Presently, the FSC certification scheme is the only active scheme for forest management in Romania. The interest in forest management certification has increased since 2012, when the first two certificates were issued for Văratec and Târgu Neamț state FDs. Presently, 2.68 million ha of forest are certified: 2.31millionha owned by the state and managed by FDs within NFA and the difference owned by different non-state owners, managed by different non-state structures. By certifying 1.6 million ha in 2013, the NFA became the most important Romanian supplier of certified wood on the European market. Regarding the traceability of wood products, more than 640 FSC certificates were issued for Romanian harvesting and processing companies [9]. Forest management and the chain of custody certification have the potential to become very important aspects of the forest sector development strategy [15], considering the increased interest in certified wood products [16]. In March 2013, the European Union Timber Regulation (EUTR) came into force as part of the European Union (EU) Law Enforcement, Government and Trade (FLEGT) Plan [17]. Through a wood products provenance monitoring system, 
EUTR aims to stop the circulation of illegally logged wood within the EU. This recent regulation (EUTR), which combines private and public policy measures with the FSC voluntary certification scheme, is becoming more prevalent in Romania and more present than ever in the public debate [18].

In this evolving context, the aims of the present study are, firstly, to evaluate the reasons for adopting the FSC certification, the changes associated with the certification, and the obstacles faced during the process. Secondly, the study aimed to evaluate the perception of uncertified FDs managers regarding FSC certification, as well as the expected benefits and possible obstacles in adopting the FSC certification. The evaluation tried to emphasize the differences between: (a) Non-state certified FDs and State certified FDs; and (b) Non-state uncertified FDs and State uncertified FDs-although we considered that the differences regarding the reasons for adopting/not adopting the forest management certification between state and non-state FDs are not significant, it is our aim to test if the benefits and changes associated with the FDs certification are perceived differently by certified and non-certified FDs, on one hand, and state and non-state FD, on the other hand.

\section{Materials and Methods}

An effective way to evaluate forest management certification is to quantify the perception of FDs managers [19]. Therefore, in order to identify the most important aspects of forest management certification in Romania, a series of meetings were held with important stakeholders of forest management and forest certification in Romania. Amongst them were members of the National Working Group for Forest Certification, high management representatives of NFA, and the coordinators of the Association of Private Forest Managers (AAP). The meetings were organized as focus groups. Based on the conclusions of the focus group discussions, four types of questionnaires were drafted, with each one addressing different types of forest management structures: non-state certified FDs, state certified FDs, non-state uncertified FDs, and state uncertified FDs. All questionnaires comprised two pages of questions, both general and specific ones, adapted to every group of FDs. The final versions of the questionnaires were elaborated after pretesting them on both state and non-state FDs managers in Brașov county. The questionnaires included Likert-scale questions and closed questions (with one or multiple choices). Because of its comprehensiveness and easiness in application, and based on the experience obtained in previous research, the five-point Likert scale was used to measure the perceived level of improvements brought about by FSC certification, expected-obtained benefits, and the main obstacles to obtaining certification. The answer options were strongly agree $=5$, agree $=4$, undecided $=3$, disagree $=2$, and strongly disagree $=1$.

The questions were meant to evaluate the FDs managers' perception (case of uncertified FDs) and FDs FSC responsible (case of certified FDs) on the reason for adopting/not adopting FSC certification, the main changes caused by the certification, economic aspects of certification, the main benefits of certification, and issues regarding the certification process (Table 1).

The questionnaires were distributed to all FDs in Romania $(n=453)$ : certified FDs $(n=220)$ and uncertified FDs $(n=233)$. For state FDs, the questionnaires were distributed through NFA headquarters and networks by electronic mail, while for non-state FDs, the questionnaires were distributed via regular mail. The regular mail was chosen for non-state FDs because of their relative resistance in using modern communication means. In many cases, the letters were presented to FDs managers in person during the general assembles of the AAP. The distribution was made following the indications of the Total Designed Method (TDM) elaborated by Dillman [20]—-the sent package included: an informative note regarding the study, the questionnaire, and a stamped envelope for assuring the retransmission of the filled questionnaire to the survey operator (for the regular mail). For the e-mail packages, repeated mails were sent for kindly reminding the respondent of the need for his/her answer.

After receiving the answers, the collected data were processed using Microsoft Office EXCEL (Microsoft Corporation, Redmond, Washington, U.S.) and Statistica ver.7 soft (StatSoft Inc.: Tulsa, OK, USA).The internal consistency of the data was analyzed by using the Cronbach $\alpha$ coefficient, for all Likert-type and multiple choice questions. The distribution of the data was checked using 
the Kolmogorov-Smirnov Test [21]; the $\mathrm{H}_{0}$ (Null) hypothesis was formulated as thedistribution of data in line with the normal distribution, while the $\mathrm{H}_{\mathrm{A}}$ (Alternative) hypothesis was formulated asthe distribution of data not in line with the normal distribution. As the data did not have a normal distribution $\left(\mathrm{H}_{0}\right.$ hypothesis was rejected, the values obtained through the Kolmogorov-Smirnov Test conducted with a significance level of $5 \%$ were less than $5 \%$ ), non-parametric tests were preferred. For examining the statistical differences among respondents' groups, we used the Mann Whitney U test, conducted with a significance level of $5 \%$ [22]. Within this scope, the $\mathrm{H}_{0}$ hypothesis was formulated as there is no difference between the groups state-private or certified-uncertified, while the $\mathrm{H}_{\mathrm{A}}$ hypothesis was formulated as there is a difference between the groups state-private or certified-uncertified. If the result of the Mann-Whitney test is significant, there is a significant difference between the two independent analyzed groups, with a subsequent high probability thatthe data represent populations with different values of the median [22].

Table 1. Constructs used in the study.

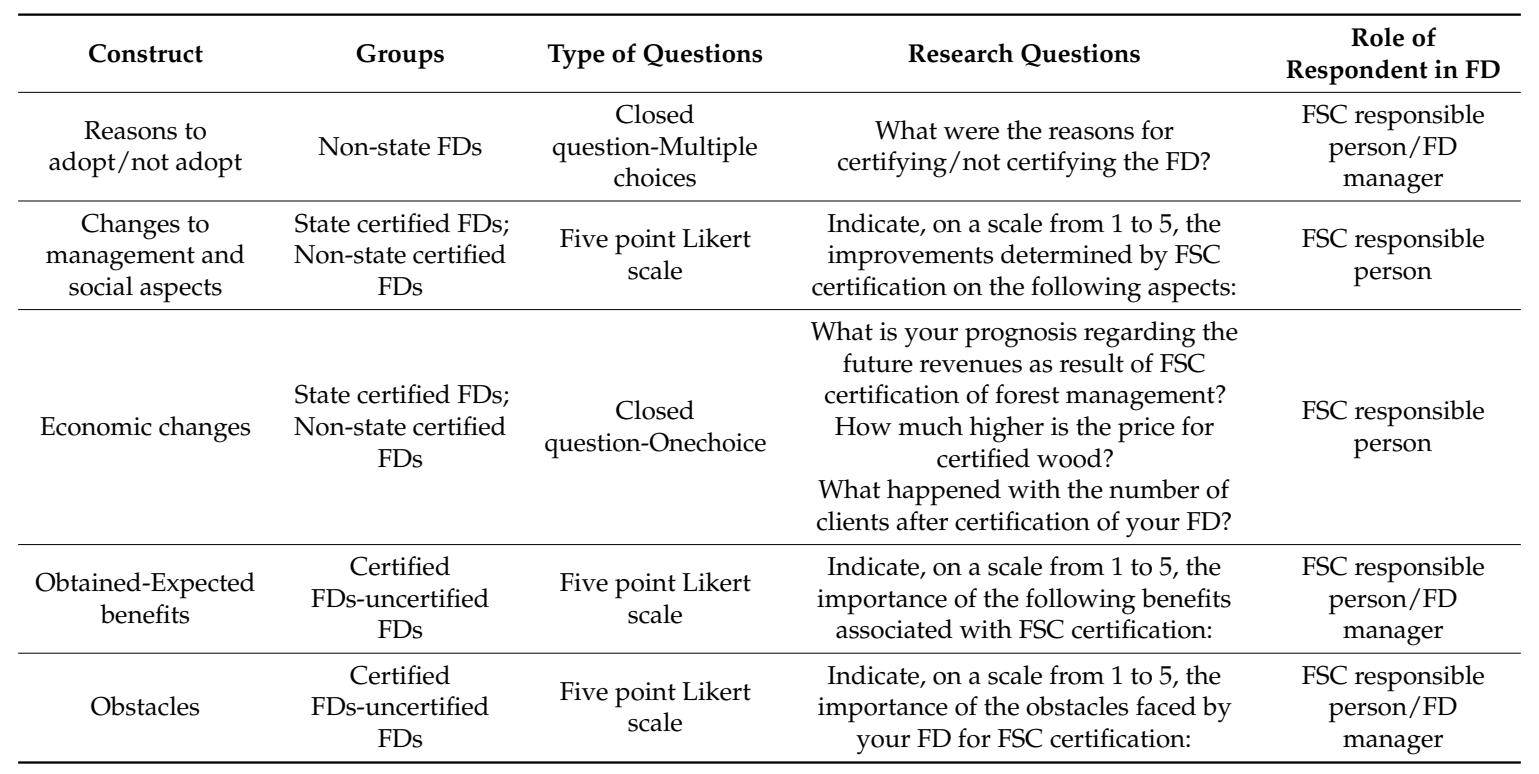

\section{Results and Discussions}

The response rate was $92 \%$, including most of the FDs in Romania, both certified and uncertified (Figure 1). The number of participants and the response rate are illustrated in Table 2.

The Cronbach $\alpha$ coefficient was calculated and the resulting values were between 0.770 to 0.915 (for all four types of questionnaire). 


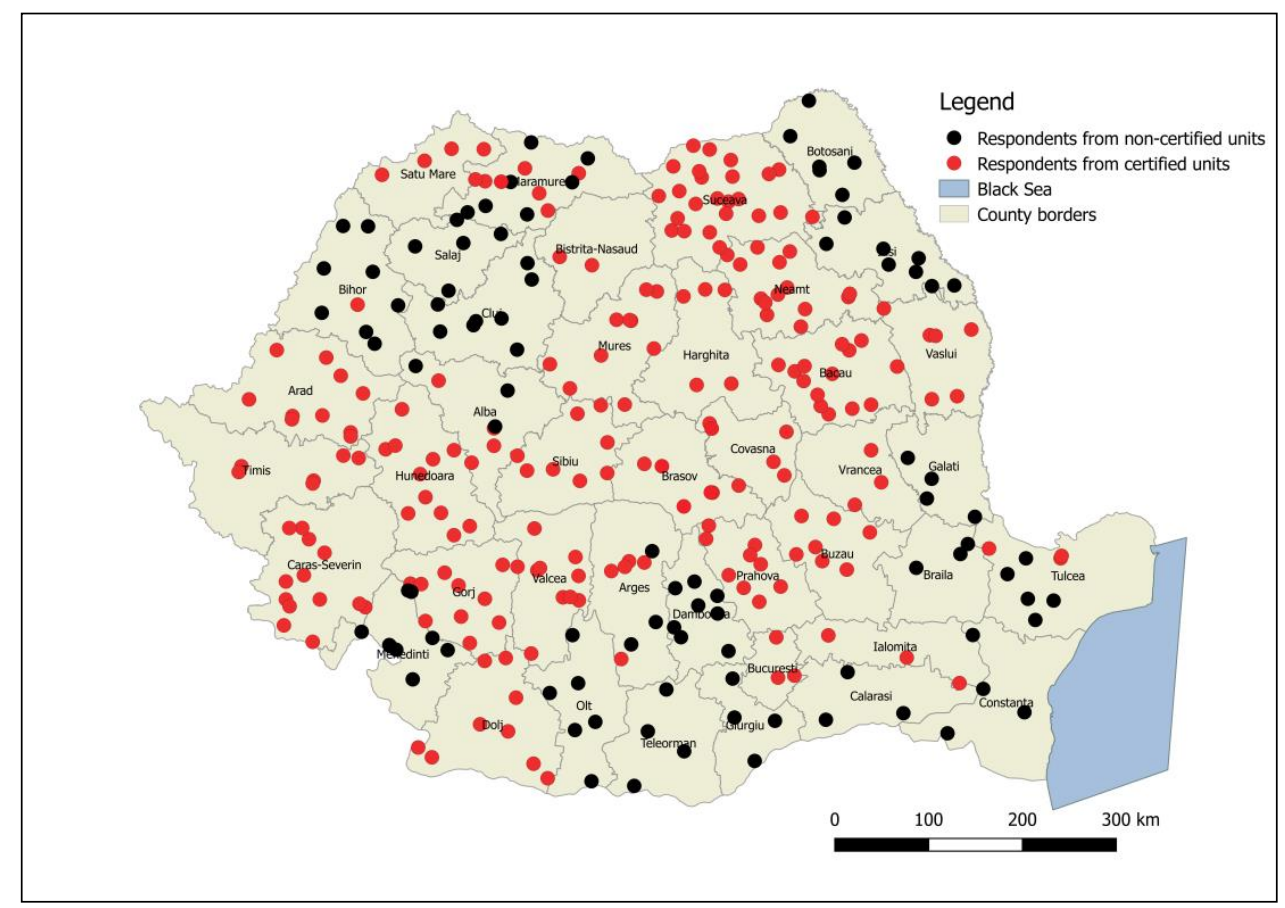

Figure 1. Map of Forest District respondents—certified and uncertified units.

Table 2. Surveyed population and response rate.

\begin{tabular}{ccccc}
\hline Respondents Categories & Population Size & $\begin{array}{c}\text { Sent } \\
\text { Questionnaires }\end{array}$ & $\begin{array}{c}\text { Completed } \\
\text { Questionnaires }\end{array}$ & $\begin{array}{c}\text { Response } \\
\text { Rate (\%) }\end{array}$ \\
\hline Non-state certified FD & 5 & 5 & 5 & 100 \\
State certified FD & 215 & 215 & 207 & 96,2 \\
Non-state uncertified FD & 132 & 132 & 102 & 77,2 \\
State uncertified FD & 101 & 101 & 98 & 97 \\
Total & 453 & 453 & 417 & 92 \\
\hline
\end{tabular}

\subsection{Reasons for Adopting FSC Forest Management Certification}

For the state FDs, the decision for adopting FSC certification was made by NFA management, with the options of FDs managers not necessarily being taken into consideration. We may only assume that the decision of NFA management was made with the aim of gaining some advantages: improved international and national reputation, financial advantages etc.

In the case of private FDs, the reasons for adopting FSC forest management certification were evaluated by analyzing the perception of forest district managers; because these are independent structures, their managers are the main promotors of forest certification. We use a closed question with multiple choices. The non-state FSC responsible persons indicated that the most frequent reasons for adopting FSC certification are: obtaining competitive advantages over other FDs, obtaining economic advantages, and improving the forest management (Figure 2). Surprisingly, although NGOs (especially WWF) had an important role in promoting forest certification, the respondents did not indicate NGOs pressures as a reason for adopting FSC certification. At the same time, also noticeable, the FSC certification was not considered as being determined by the need for wood commerce regulation compliance, but aimed to get some economic benefits and competitive advantages over other uncertified FDs and to improve the forest management. 


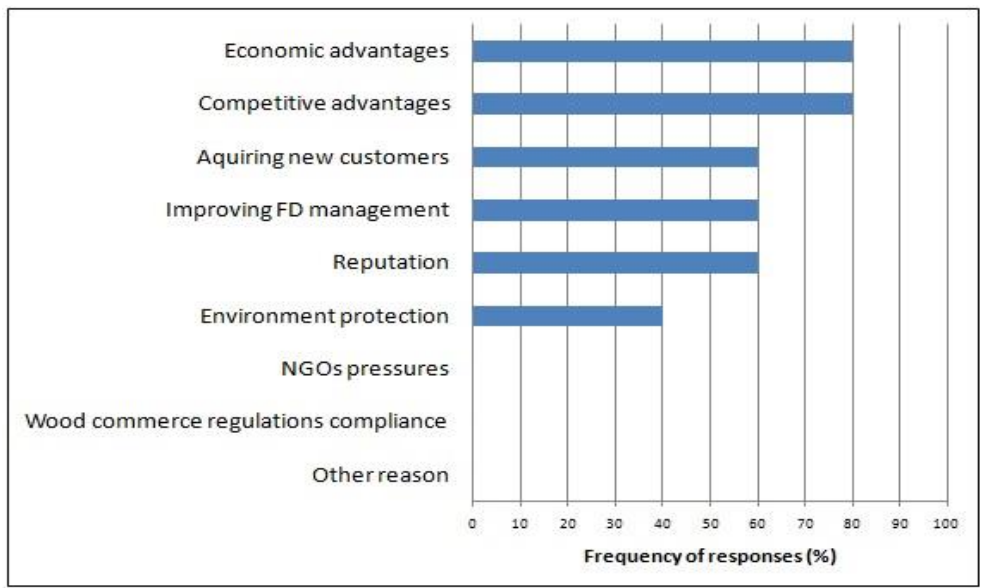

Figure 2. Reasons for adopting FSC certification as indicated by non-state certified FDs managers (Multiple choice question: What were the reasons for certifying the FD?) (in Supplementary).

At an international level, Lidestav and Lejon [23] claim that, in Sweden, the same reasons basically justified the decision to adopt forest certification, which was perceived as a profitable tool. In Slovakia and Japan, forest management improvement, forest administrators' image, and customer relations were the main reasons for adopting forest certification [5,24]. Tikina et al. [25], by studying the perception of certified forest owners on the west coast of the Pacific Ocean, highlight that the market pressure was the determinant factor in deciding to adopt forest certification. The non-state FDs managers' perception confirms the expert opinion: forest management experts and certification auditors in Romania consider that FSC forest certification aims towards obtaining some economic advantages, often with support from NGOs, in the case of FDs, or just a consequence of customers' pressure, in the case of harvesting and processing companies [26].

\subsection{Reasons for Not Adopting FSC Forest Management Certification}

In state owned forests, the decision of adopting/not adopting FSC certification was taken at the central level by the management of NFA. Thus, evaluating the reasons for not adopting FSC certification by asking state FDs managers was difficult.

In non-state FDs, the most frequent answer concerning the reasons for not adopting FSC certification was the high cost of FSC certification (69\%). Another identified reason was the refusal of owners, as well as the lack of information on forest certification (Figure 3).

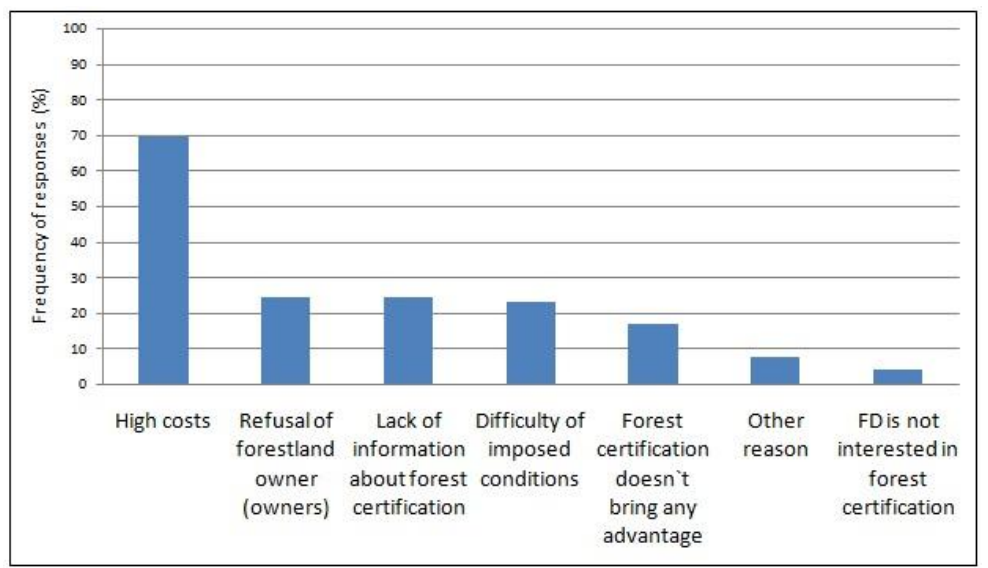

Figure 3. Reasons for not adopting FSC certification-the case of non-state Forest Districts (Multiple choice question (in Supplementary): What were the reasons for not certifying the FD?). 
At an international level, similar results were obtained in Japan regarding obstacles in FSC certification [5]. Similar studies in other countries [27] mention economic aspects (costs of certification) and the level of information regarding how a certain certification scheme works as the main barriers in the adoption of forest certification.

To evaluate the potential of FSC certification as a useful tool in obtaining economic advantages, non-state uncertified FDs managers were asked if they consider themselves disadvantaged by the fact that wood buyers may choose to buy certified wood from state certified FDs following the certification of more than 2.3 million ha state-owned forest land. The answers (Figure 4) indicate that most of the respondents (63\% of the managers of non-state uncertified FDs) reported that there will be no special disadvantage because customers will continue to purchase uncertified wood. However, $28 \%$ of the respondents considered that the certification of state-owned forestland will bring disadvantages to uncertified non-state FDs (Figure 4).

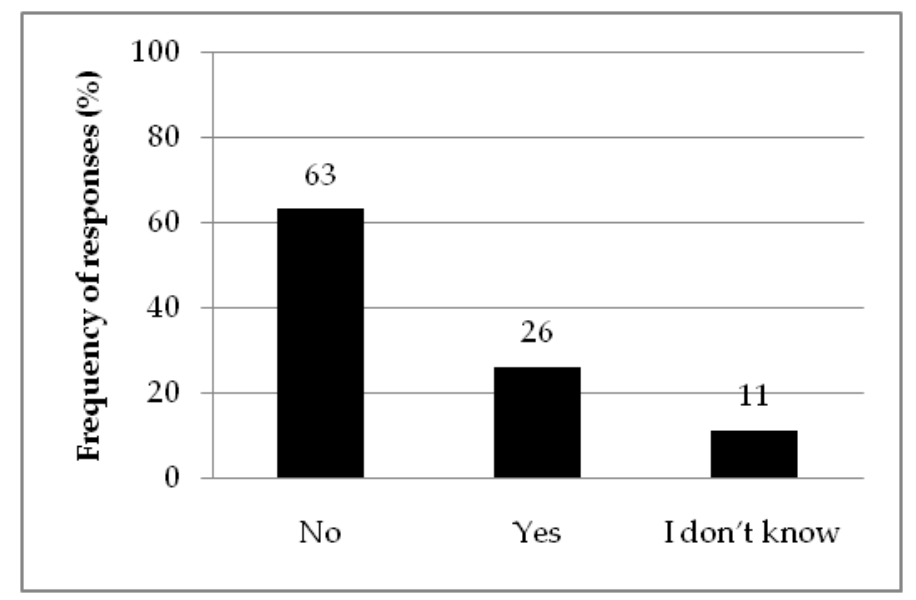

Figure 4. Answers of uncertified non-state FDs managers to the question: Will the certification of more than 2.3 million ha of state-owned forestland disadvantage our FD because of the customers switch towards certified wood (in Supplementary)?

\subsection{Changes in Forest Management after FSC Certification}

Managers of certified FDs were asked to outline the main changes determined by the certification to forest management, social, and economic environments. As far as forest management is concerned, in both non-state and state FDs, the FSC responsible persons indicated major changes in the usage of chemicals and measures for protecting endangered species and protected areas, as well as in monitoring and surveillance (Figure 5). Respondents considered that FSC certification did not bring about changes in forest management plans (Figure 5).

When comparing the answers provided by the two categories (state and non-state) of certified FDs by using the Mann Whitney $U$ test, the results indicated that there were no major differences between the two groups when referring to the changes brought about by forest certification to forest management, with $p$ values being over 0.05 . Some differences exist between the average values of the two categories in terms of the matter of improving the informational system-non-state FDs FSC responsible persons indicated more important changes (3.75 average value, standard deviation: 1014) than the state FDs FSC responsible persons (2.88 average value, standard deviation: 0.174$)$.

In many other countries, changes in forest management planning, due to forest certification, were considered as being important. For instance, Alemagi et al. [28] in a study undertaken over the certified forest management units in North America, shows that the main changes determined in forest management were forest management planning itself, together with conservation and monitoring measures. Cubbage et al. [19], in a study conducted in Argentina and Chile, mention that 
essential changes required were brought about by forest certification in forest management planning, endangered species protection, and the usage of chemicals.

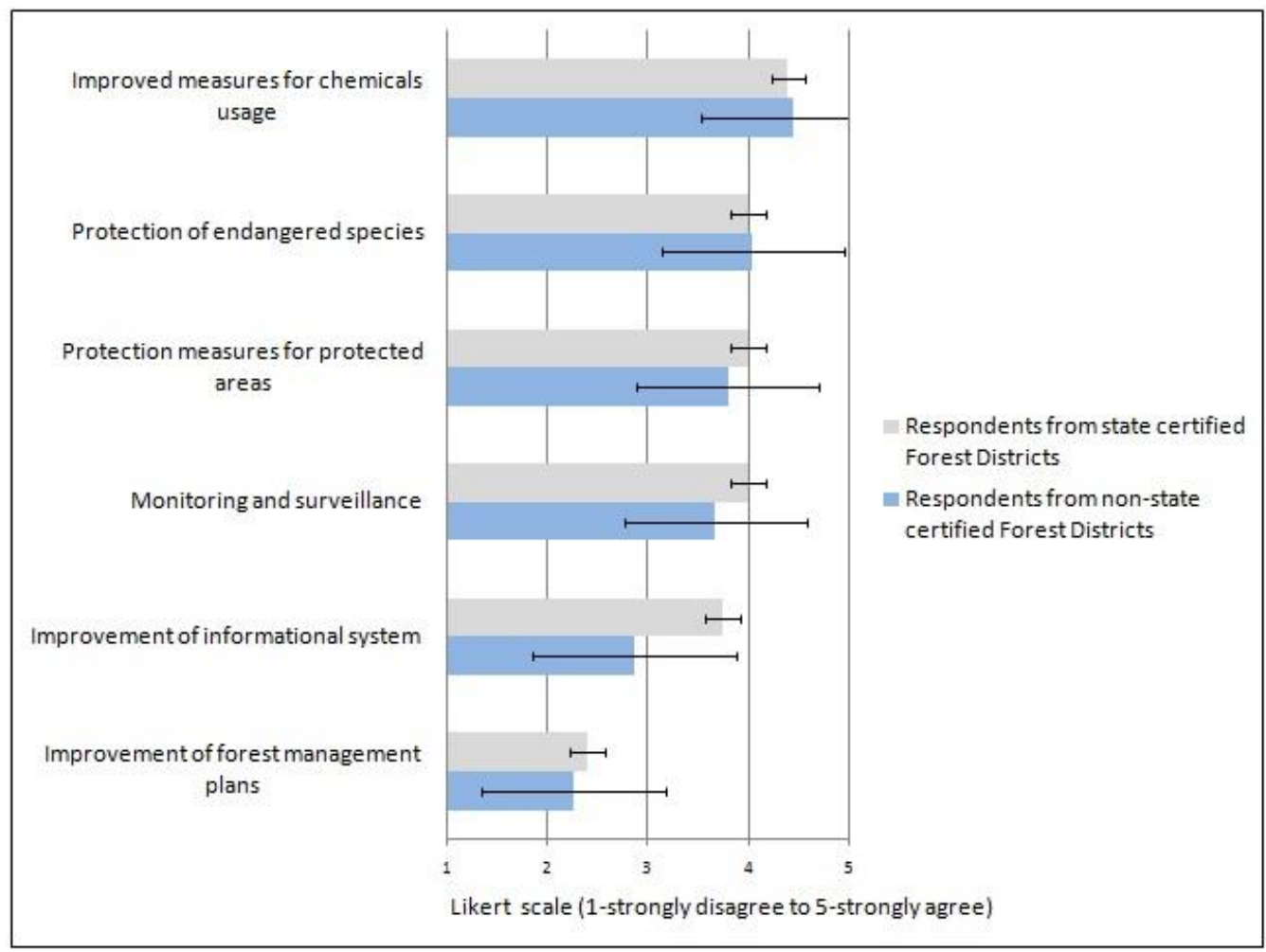

Figure 5. FDs FSC responsible persons perception over the changes brought to forest management by FSC forest management certification (Likert scale question: Indicate, on a scale from 1 to 5, the improvements determined by FSC certification on the analyzed aspects (in Supplementary)).

\subsection{Changes in Social Aspects of Forest Management after FSC Certification}

On the matter of social aspects, important changes indicated by the non-state FDs FSC responsible persons referred to improvements in the relationships with NGOs and with the general public (3.8 respectively 3.6 Likert scores). At the same time, non-state FDs FSC responsible persons considered that FSC is important due to the necessity of consulting decision makers (score 4). This important change brought about by the FSC certification is indicated by other studies, too [29,30]. Humphries and Kainer [30], based on analyzing the auditing reports, show that training and communication with forest management decision makers were the main changes brought about by FSC to social aspects. The FSC study [31] also underlines that stakeholders appreciated FSC certification for the necessity to undertake consultations with different forest management stakeholders.

On the matter of illegal logging, the non-state FDs FSC responsible persons opinion showed that the FSC certification is not effective (no changes, score 1.6, standard deviation: 0.244), considering that a rather high level of illegal logging is already recognized in the case of Romania [32].The low score of working rights compliance (score 2, standard deviation: 0.094) can be explained by the already enforced prescriptive regulatory framework. For these two aspects-illegal logging and working rights compliance-the state certified FDs FSC responsible persons also awarded low scores, although they are bigger than the ones awarded by the non-state FDs FSC responsible persons (score 2.5 for reducing illegal logging and 3.07 for working rights compliance).No noticeable changes were perceived in terms of petition solving or of the protection of local communities' rights by the non-state FDs FSC responsible persons. 
State FDs FSC responsible persons indicated consultations with local communities (score 3.96, standard deviation: 0.076) and public information (score 3.92) as being the most important changes brought about by FSC certification (Figure 6). Transparency and clear records (score 3.82, standard deviation: 0.078 ) and consultations with decision makers (score 3.79, standard deviation: 0.072) were indicated as important changes after FSC certification (Figure 6).

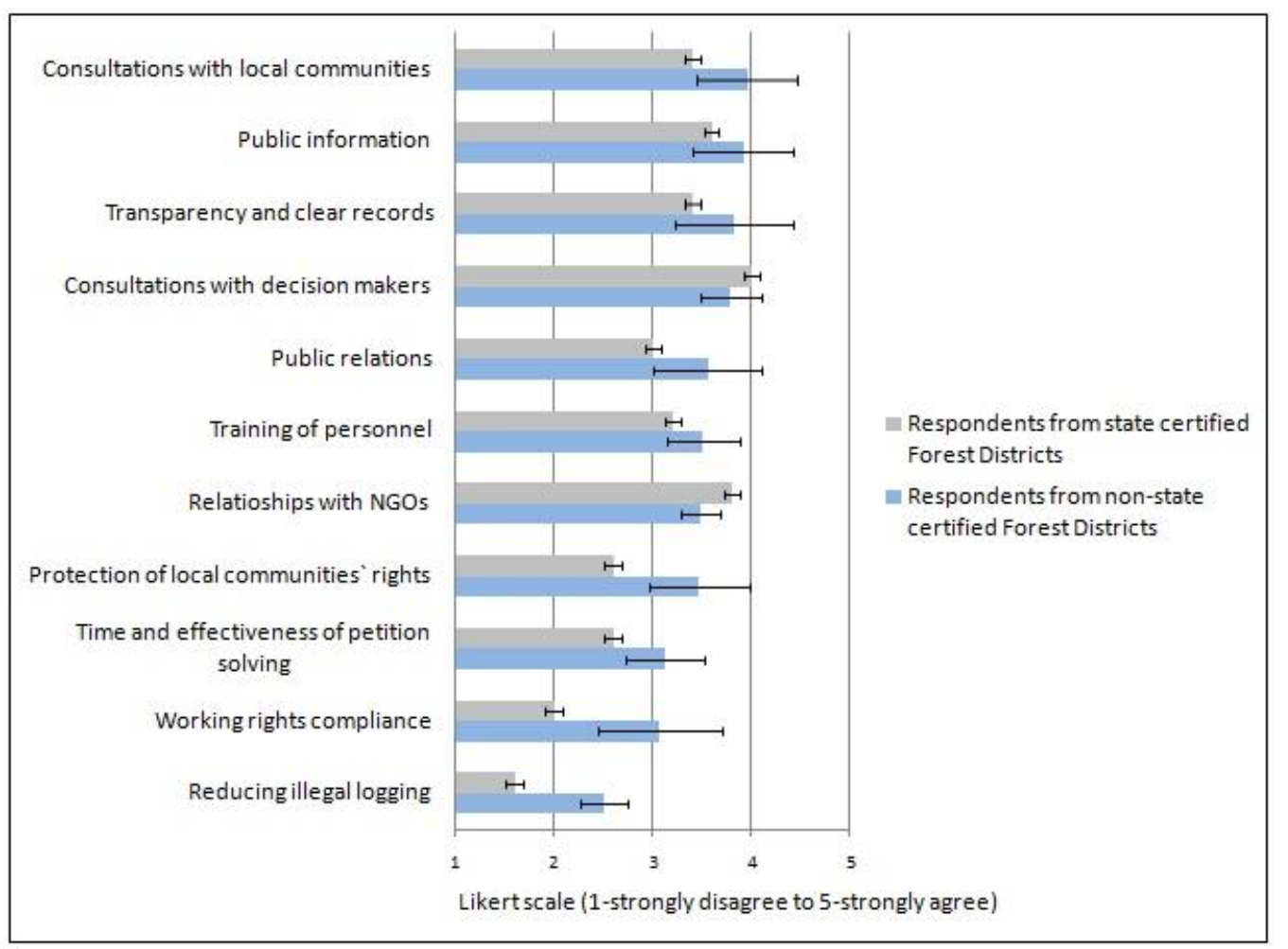

Figure 6. FDs FSC responsible persons' perception over the changes brought to social aspects by FSC forest management certification (Likert scale question: Indicate, on a scale from 1 to 5 the improvements determined by FSC certification on the analyzed aspects (in Supplementary)).

The perceptions of the two groups of respondents (state and non-state FDs FSC responsible persons) on the social aspects impacted by FSC forest certification are relatively close, with some differences in matters related to local communities'rights, petition solving, working rights compliance, or illegal logging (Figure 6), a situation that can be found in other studies, too [19]. The non-state FDs FSC responsible person sconsidered that the impact of FSC certification on these matters is small, while state FDs FSC responsible persons gave higher scores. When comparing the answers provided by the two categories (state and non-state) of certified FDs by using the Mann Whitney U test, the results indicated that there are no major differences between the two groups in terms of the changes associated with forest certification and social aspects.

The results of this study can be compared with other studies addressing the social aspects of forest management certification. For instance, in a study done for Rainforest Alliance in 21 countries with FSC certified forests, Newsom and Hewitt [29] found that the FSC certification social impacts are positively important through employees training and assuring proper protection equipment, thus reducing working injuries. Besides these benefits, the FSC report [31] highlights that another important benefit is the in-time payment of salaries. Bostrom [33] also found that the certification is useful, especially in developing countries, by making better connections with good international regulatory practices. Aspects related to labor regulations are indicated as more important than social and cultural aspects [33]. Also, health and safety aspects combined with a stakeholder's consultation appeared to be more often the case for non-conformities in Eastern Europe than they were in the 
western part of the continent [34,35]. An important aspect of the certification, indicated as such by the forest managers and certification auditors in Romania [26], is the fact that forestry—related legislation in Romania is more than sufficient for implementing sustainable forest management, but the legislation enforcement may face some issues. Nevertheless, once adopted, the FSC certification introduces some supplementary requirements that are not demanded by the specific Romanian legislation [26].

\subsection{Changes of Economic Aspects after FSC Certification}

The FDs FSC responsible persons were asked about the effects of certification on FDs revenues. In total, $58 \%$ of the respondents indicated that the revenues did not increase after certification, while $42 \%$ considered that the FSC certification positively influenced the revenues. The distributions in the answers to this question were not significantly different between state and non-state FDs ( $58 \%$ of the state FDs FSC responsible persons and 57\% of the non-state FDs FSC responsible persons indicated that revenues will increase).

They were also asked to make a rough prognosis regarding the future revenues: $54 \%$ of the state FDs FSC responsible persons indicated that the revenues will increase in the next period, due to certification, while $44 \%$ reported that the revenues will remain unchanged. Only $2 \%$ of the respondents considered that the revenues will decrease (Figure 7). Responses did not significantly differ when comparing state/non-state FDs FSC responsible persons.

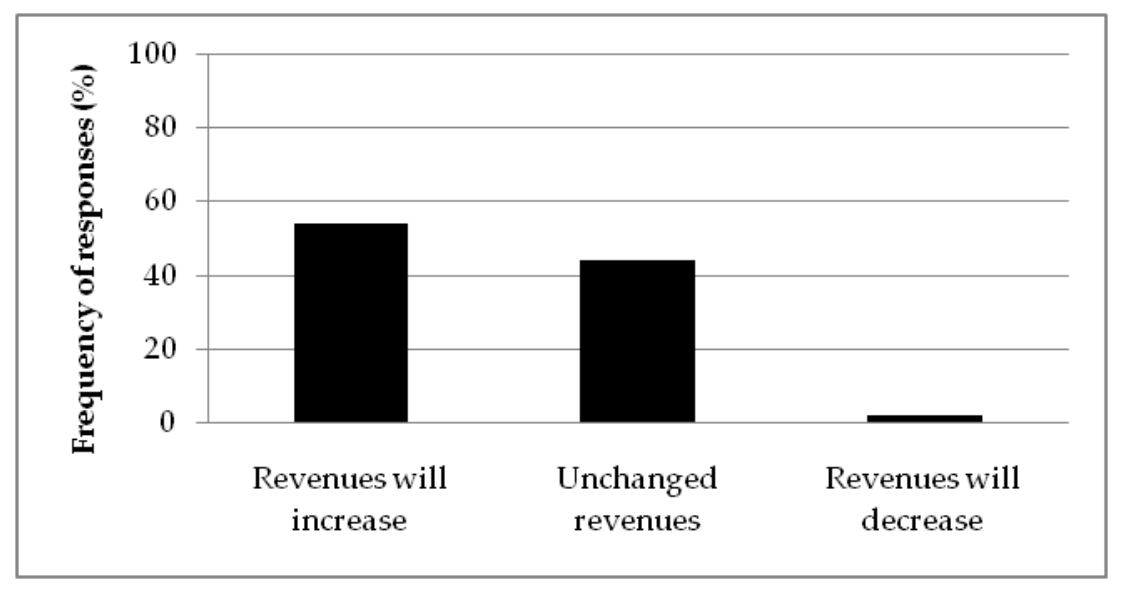

Figure 7. FDs FSC responsible persons' answers to the question: What is your prognosis regarding the future revenues as result of FSC certification of forest management? (in Supplementary).

Regarding the sold certified wood, $61 \%$ of the FDs FSC responsible persons considered that the certified wood did not have a higher price than the uncertified wood. Among the respondents who considered that there is a premium price for the certified wood ( $39 \%$ of the total 207 respondents), $52 \%$ considered that the price was higher by 5 to $10 \%$ as compared to the uncertified wood, while $32 \%$ considered that the price difference was lower than $5 \%$ (Figure 8 ). 


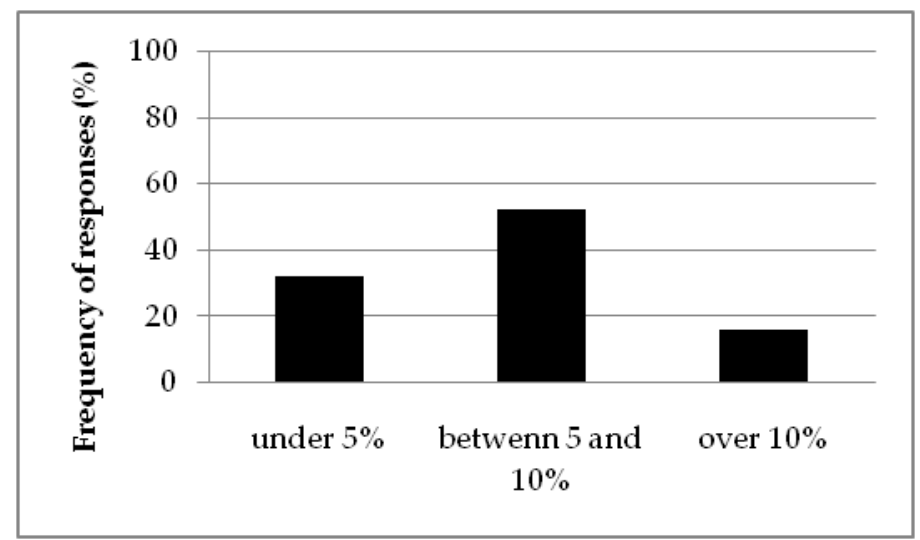

Figure 8. FDs FSC responsible persons answers to the question: How much higheris the price for certified wood? (in Supplementary).

Most of the FDs FSC responsible persons (77\%) considered that the FSC certification did not bring about any changes in the number of customers, with only $21 \%$ of the respondents having the perception that the number of customers increased due to FSC certification (Figure 9).

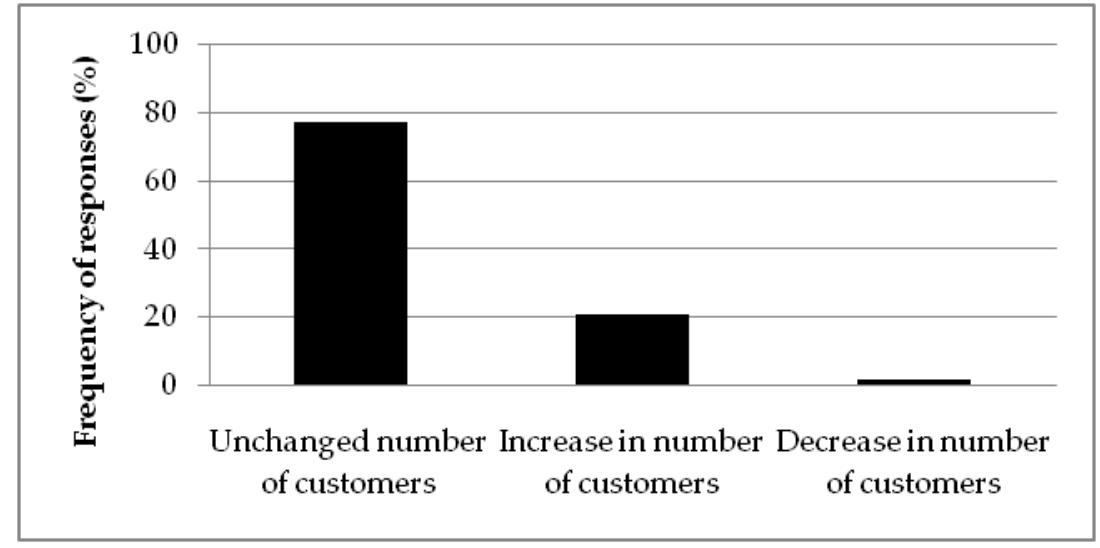

Figure 9. Perception of FDs FSC responsible persons regarding the impact of FSC certification on the number of customers (Question: What happened with the number of clients after certification of your FD?) (in Supplementary).

The fact that the certification does not always result in a substantial price premium is often present in the literature. For instance, a study undertaken in Japan [36] indicates that the economic changes were rather minimal, with no premium price for certified products.

A study which unfolded in Brazil [37] also indicates the absence of economic advantages associated with premium prices for certified wood. After surveying the stakeholders involved in the process of forest certification in Europe, Araujo et al. [38] found out that most of the companies had the same price for both certified and uncertified products. In Romania, the FSC certified companies also consider that the premium price was not among the benefits of FSC certification [15]. There are numerous discussions regarding the premium price of wood products as a result of certification, especially from the perspective of companies that sell wood products. Zhao et al. [39] presented the situation of China with an internal wood products market insufficiently mature, with almost all products being exported and no premium price recorded. Chen et al. [40] evaluate the attitude of the Chinese companies towards certification, indicating that the premium price was not necessarily the reason for certification, but other market benefits. Espach [41] offers a more optimistic image of the 
premium price by showing that the FSC certified wood exported from Brazil had a $20 \%-50 \%$ higher price, while in Bolivia, the premium price varied between 5\%-51\% [42].

\subsection{Different Perceptions onFSC Certification Benefits}

The uncertified FDs managers were asked to rank the expected benefits of certification, while the FDs FSC responsible persons were asked to rank the obtained benefits. When analyzing the results by using the Mann Whitney U test, we identified significant differences between the two groups-an indicator that certification brought about different benefits than the expected ones.

The most significant differences between the perceptions of the two groups appeared in relation to the economic aspects (increased profitability, sales increase, new customers, increased sales prices): uncertified FDs managers considered them more important, while FDs FSC responsible persons indicated that these benefits of certification were so small that they were not that important (Figure 10). Only for aspects like worker's safety, monitoring and control, or the relationships with mass-media and NGOs is the perception of the two groups not significantly different. These aspects were the most important benefits of the certification in the FDs FSC responsible persons'perception. The same differences were identified in studies conducted in the north-west of Russia [43].

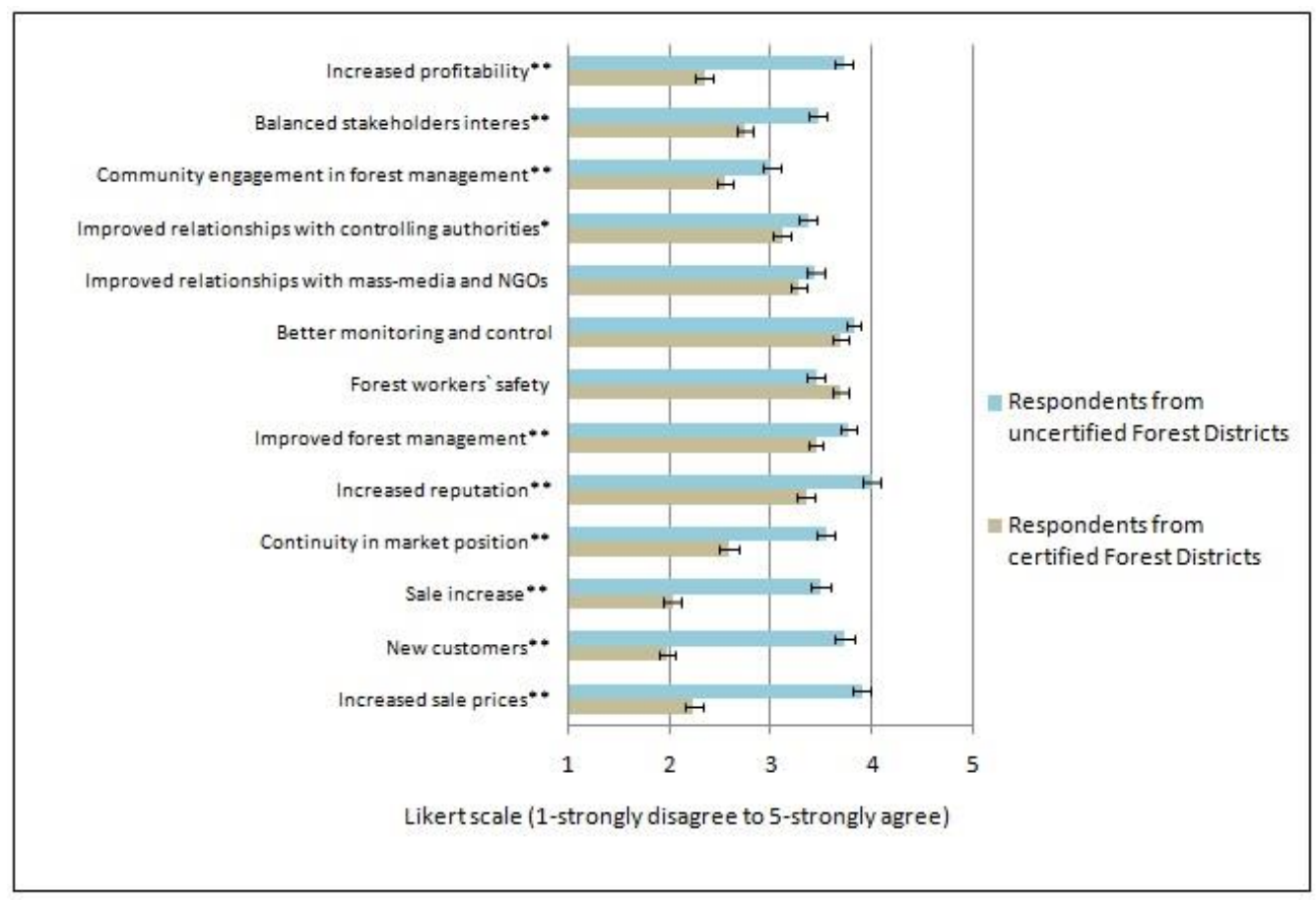

Figure 10. Perception of FDs managers and FDs FSC responsible persons regarding the expected/obtained benefits of FSC certification (Mann Whitney U test: ${ }^{*} p<0.05 ;{ }^{* *} p<0.01$ ) (Likert scale question: Indicate, on a scale from 1 to 5 , the importance of the analyzed benefits associated with FSC certification) (in Supplementary).

\subsection{Different Perceptions on Obstacles in Adopting FSC Certification}

As indicated by forest management experts and certification auditors [26], the most important issues in adopting the FSC certification in Romania are: costs, lack of sufficient information, and difficulties in implementing the FSC standard, with these issues being expressed by the respondents of our survey, too. The perceptions are statistically different between the two groups-certified and uncertified FDs. Uncertified FDs mangers awarded most of the identified obstacles with higher scores of importance compared with the scores of FDs FSC responsible persons. Significant perception differences 
appeared in problems such as separating certified from uncertified wood, cost of certification, lack of information, and low customers' interest for certified products (Figure 11).

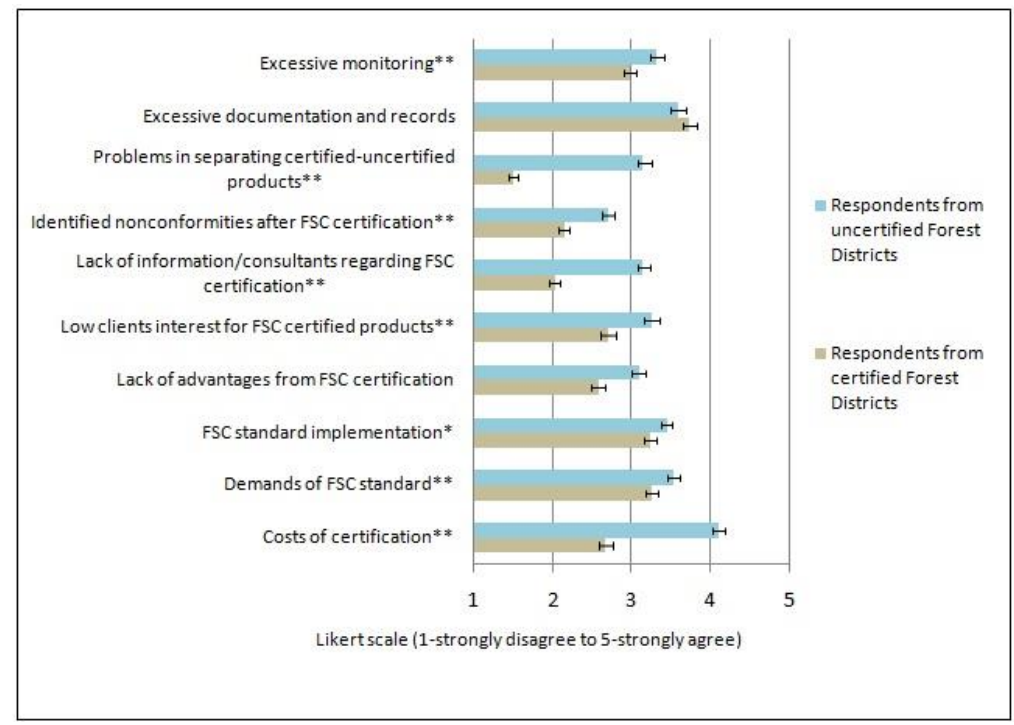

Figure 11. Perception of FDs managers and FDs FSC responsible persons regarding the obstaclesfaced for FSC forest management certification (Mann Whitney U test: ${ }^{*} p<0.05 ;{ }^{* *} p<0.01$ ) (Likert scale question: Indicate, on a scale from 1 to 5 , the importance of the obstacles faced by your FD for FSC certification) (in Supplementary).

By using the Mann Whitney U test, wefound statistically different perceptions between the two groups of respondents, except for the aspects related to documentation and records (Figure 11). For instance, the cost of certification was perceived as a major problem for uncertified FDs managers, while representatives from certified FDs considered this issue as less important. No significant differences in the perception of the two groups were identified, only in that certification requires supplementary documentation and records (Mann Whitney $\mathrm{U}: p=0.291$ ), which entails additional effort and resources.

Concordant results can be found in other studies [27,30], indicating that the main problems faced during the certification are the demands of the standard, the costs, and the difficulty in understanding the process. In other studies conducted in Romania, forest management experts and certification auditors indicated that the certification is closely linked to the demand for certified products ona short and medium term, with this having the potential of an increased interest for the access to FSC certified wood products, while elaborating and implementing Romanian national specific FSC standards may represent a solution to a more adapted certification process [26].

\section{Conclusions}

This study gives useful evaluations on the targeted aspects. It also helps understand the role of forest certification in solving Romanian forestry sector issues. The dynamic of the Romanian forest sector, after the change of the regime in 1989, profoundly affected the structure of ownership, the wood products markets, and the relationship of the sector with the society [44]. In this section, we will show how the results of the present study prove that forest management certification, the FSC scheme in this case, is perceived as potentially being among the solutions for problems determined by the changes in all these three areas.

On the matter of changed ownership structure, the rise of non-state ownership and the development of a powerful private sector in forest management created different attitudes towards certification among state or non-state FDs managers. Against initial assumptions, the reasons of 
non-state FDs for adopting the certification differed from the expected benefits of state FDs. Non-state management structures, directly and independently facing the rigors of the free market, voluntarily adopted the FSC certification with the initial aims of, firstly, obtaining economic advantages and, secondly, improving their forest management. The state FDs grouped under NFA, facing a degraded image in front of the society, firstly expected improved reputation and relationships with the society and, secondly, economic benefits and better forest management.

On the matter of wood products, the evolution of markets, the disappearance of the state monopoly, and the transition to a market economy determined non-state forest management structures to seek, through FSC certification, solutions to some of their economic problems: revenues, pressures from customers, and prices. Most of them did not perceive these initial reasons as benefits of the certification after the end of the process. Changes of economic aspects after the certification existed to a reduced extent. Most of the non-state FDs FSC responsible persons considered that revenues did not increase after the certification, nor did the prices and the number of customers, with the perception being the same for state FDs. Some situations of premium prices for wood were recorded, but they were mainly local and displayed a reduced increase of the price. However, we need to consider the short period between the adoption of certification and the survey described in this study, and take account of the fact that the forest management experts and certification auditors in Romania expect an increase in the demand for certified wood on a short and medium term. These expectations are at least partially fulfilled by the evolution of the chain of custody certification in the last few years-from 214 certificates in 2014 to more than 640 certificates in 2018.

On the matter of the relationships of the forest sector with the society, changes in social and societal aspects determined by forest management certification are important in the perception of all FDs FSC responsible persons in Romania. Most of the managers of these structures, irrespective of the type of structure (state or non-state FDs), acknowledged the high importance of the changes determined by certification in areas like consultation with stakeholders, including local communities and civil society, transparency and clear records, community engagement in forest management, or areas such as the use of chemicals and biodiversity protection. Despite all the differences between expectations and achievements, there is a common perception amongst forest management structures that certification can improve forest management in general. Still, FSC certification did not solve all the problems of the forest sector in Romania. Issues like illegal logging or prescriptive regulations are perceived as still pending, for both state and non-state FDs FSC responsible persons. Nevertheless, the orientation towards adopting voluntary instruments to promote and prove performant sustainable forest management is a strong indicator of the willingness of the Romanian forest management sector to cope with the market and trends and clarify its position in society. Designing national specific FSC certification standards may be the next step that will support a coherent relation among the certification system demands, the national legislation, and the specific issues, and will bring the whole sector closer to the aim of the society and to integrated economic sustainable forest management.

Supplementary Materials: The following are available online at http:/ / www.mdpi.com/1999-4907/9/7/425/ s1, 1. Questionnaire for non-state certified Forest districts; 2. Questionnaire for uncertified non-state FDs; 3. Questionnaire for certified forest districts-NFA Romsilva; 4. Questionnaire for uncertified state FDs-NFA Romsilva.

Author Contributions: A.F.H. designed and performed the surveys, analyzed the data, and wrote the manuscript. I.V.A. and B.P. designed the research and revised the manuscript.

Funding: This study was financially supported by Transilvania University of Brasov.

Acknowledgments: The authors are grateful to the Romanian National Working Group for Forest Certification, the National Forest Administration-Romsilva and the Association of Private Forest Managers for their collaboration and especially for their support in disseminating the questionnaires.

Conflicts of Interest: The authors declare no conflict of interest. 


\section{References}

1. Fromond, L.; Similä, J.; Suvantola, L. Regulatory innovations for biodiversity protection in private forests-towards flexibility. J. Environ. Law 2009, 2, 1-31. [CrossRef]

2. Pappila, M. Forest certification and trust-Different roles in different environments. For. Policy Econ. 2013, 31, 37-43. [CrossRef]

3. Bartley, T. Certifing Forests and Factories: States, Social Movements, and Rise of Private Regulation in the Appareland Forest Products Field. Polit. Soc. 2003, 31, 433-464. [CrossRef]

4. Overdevest, C. Comparing forest certification schemes: the case of ratcheting standards in the forest sector. Socioecon. Rev. 2009, 8, 47-76. [CrossRef]

5. Sugiura, K.; Oki, Y. Reasons for Choosing Forest Stewardship Council (FSC) and Sustainable Green Ecosystem Council (SGEC) Schemes and the Effects of Certification Acquisition by Forestry Enterprises in Japan. Forests 2018, 9, 173. [CrossRef]

6. Stringer, C. Forest Certification and changing global commodity chains. J. Econ. Geogr. 2006, 6, 701-722. [CrossRef]

7. Pattberg, P.H. The Forest Stewardship Council: Risk and Potential of Private Forest Governance. J. Environ. Dev. 2005, 14, 356-374. [CrossRef]

8. FSC International. FSC-STD-20-007 Standard: Forest Management Evaluations; FSC International: Bonn, Germany, 2009.

9. Forest Stewardship Council Site. Available online: http//:www.info.fsc.org (accessed on 15 April 2018).

10. Abrudan, I.V.; Marinescu, V.; Ionescu, O.; Ioras, F.; Horodnic, S.A.; Sestras, R. Developments in the Romanian Forestry and its Linkages with other Sectors. Not. Bot. Horti Agrobot. 2009, 37, 14-21.

11. The Romanian Forest Act. Law 48. 2008.

12. Abrudan, I.V. A decade of non-state administration of forests in Romania: Achievements and challenges. Int. For. Rev. 2012, 14, 275-284. [CrossRef]

13. Marinchescu, M.; Halalisan, A.F.; Popa, B.; Abrudan, I.V. Forest Administration in Romania: Frequent Problems and Expectations. Not. Bot. Horti Agrobot. 2014, 42, 588-595. [CrossRef]

14. Dragoi, M.; Popa, B.; Blujdea, V. Improving communication among stakeholders through ex-post transactional analysis-Case study on Romanian forestry. For. Policy Econ. 2011, 13, 16-23. [CrossRef]

15. Halalisan, A.F.; Marinchescu, M.; Popa, B.; Abrudan, I.V. Chain of Custody certification in Romania: profile and perceptions of FSC certified companies. Int. For. Rev. 2013, 15, 305-314. [CrossRef]

16. FSC International. FSC MARKET INFO PACK. Available online: https:/ /ic.fsc.org/en/for-business/fsctools/local-market-successes / fsc-market-info-pack (accessed on 15 April 2018).

17. European Union. Regulation (EU) No 995/2010 of the European Parliament and of the Council of 20 October 2010 laying down the obligations of operators who place timber and timber products on the market. Available online: http:/ / eur-lex.europa.eu/legal-content/EN/TXT/?uri=CELEX:32010R0995 (accessed on 27 June 2018).

18. Gavrilut, I.; Halalisan, A.F.; Giurca, A.; Sotirov, M. The interaction between FSC certification and the implementation of the EU timber regulation in Romania. Forests 2015, 7, 3. [CrossRef]

19. Cubbage, F.; Diaz, D.; Yapura, P.; Dube, F. Impacts of forest management certification in Argentina and Chile. For. Policy Econ. 2010, 12, 497-504. [CrossRef]

20. Dillman, D.A. Mail and Telephone Surveys-The Total Design Method; Wiley Interscience: New York, NY, USA, 1978; Volume 3, p. 341.

21. Zar, J.H. Biostatistical Analysis; Prentice-Hall Inc.: Englewood Cliffs, NJ, USA, 1974; 621p.

22. Sheskin, D.J. Handbook of Parametric and Nonparametric Statistical Procedures, 3rd ed.; CRC Press: Boca Raton, FL, USA, 2003.

23. Lidestav, G.; Lejon, S.B. Forest certification as an instrument for improved forest management within small-scale forestry. Small-Scale For. 2011, 10, 401-418. [CrossRef]

24. Palus, H.; Kaputa, V. Survey of attitudes towards forest and chain of custody in the Slovak Republic. Drewno-Wood 2009, 52, 182.

25. Tikina, A.; Kozak, R.; Larson, B. What factors influence obtaining forest certification in the US Pacific Northwest? For. Policy Econ. 2008, 10, 240-247. [CrossRef] 
26. Halalisan, A.F.; Marinchescu, M. Forest Certification in Romania: The View of the Experts. In Proceedings of the Biennial International Symposium Forest and Sustainable Development; Abrudan, I.V., Borz, A.S., Curtu, A.L., Drosos, V.C., Ignea, G., Indreica, A., Ionescu, O., Ioras, F., Pacurar, V.D., Peltz, D., et al., Eds.; Transilvania University Press: Brasov, Romania, 2015; pp. 104-109.

27. Alemagi, D.; Hajjar, R.; David, S.; Kozak, R.A. Benefits and barriers to certification of community-based forest operations in Cameroon: An exploratory assessment. Small-Scale For. 2012, 11, 417-433. [CrossRef]

28. Moore, S.E.; Cubbage, F.; Eicheldinger, C. Impacts of Forest Stewardship Council (FSC) and Sustainable Forestry Initiative (SFI) forest certification in North America. J. For. 2012, 110, 79-88. [CrossRef]

29. Newsom, D.; Hewitt, D. The Global Impacts of Smartwood Certification; Final Report for Trees Program; Rainforest Alliance: New York, NY, USA, June 2005.

30. Humphries, S.S.; Kainer, K.A. Local perceptions of forest certification for community-based enterprises. Forest Ecol. Manag. 2006, 235, 30-43. [CrossRef]

31. FSC International. FSC reflected in scientific and professional literature. Literature study on the autcomes and impact of FSC certification. FSC Policy Series No. 2009-P001. Available online: https://www.hcvnetwork. org/resources/folder.2006-09-29.6584228415/Impacts_report_-_Karmann_2009.pdf/view (accessed on 15 April 2018).

32. Bouriaud, L. Causes of illegal logging in Central and Eastern Europe. Small-Scale For. 2005, 4, $269-291$.

33. Bostrom, M. The problematic social dimension of sustainable development: the case of the Forest Stewardship Council. Int. J. Sustain. Dev. World 2012, 19, 3-15. [CrossRef]

34. Hain, H. The Role of Voluntary Certification in Promoting Sustainable Natural Resource Use in Transitional Economies. Ph.D. Thesis, University of Tartu, Tartu, Estonia, May 2012.

35. Halalisan, A.F.; Ioras, F.; Korjus, H.; Avdibegovic, M.; Maric, B.; Malovrh, S.P.; Abrudan, I.V. An analysis of forest management non-conformities to FSC standards in different European countries. Not. Bot. Horti Agrobot. 2016, 44, 634-639. [CrossRef]

36. Sugiura, K.; Yoshioka, T.; Inoue, K. Effects of aquiring FSC forest management certification for Japanese enterprises using SmartWood Audits. J. Forest Res. 2012, 23, 165-172. [CrossRef]

37. Araujo, M.; Kant, S.; Couto, L. Why Brazilian companies are certifying their forests? For. Policy Econ. 2009, 11, 579-585. [CrossRef]

38. Gomez-Zamalloa, M.G.; Caparros, A.; Ayanz, A.S.-M. 15 Years of Forest Certification in the European Union. Are we doing things right? Forest Syst. 2011, 20, 81-94. [CrossRef]

39. Zhao, J.; Xie, D.; Wang, D.; Deng, H. Current status and Problems in Certification of Sustainable Forest Management in China. Environ. Manag. 2011, 48, 1086-1094. [CrossRef] [PubMed]

40. Chen, J.; Innes, J.L.; Kozak, R.A. An exploratory assessment of the attitudes of Chinese wood products manufacturers towards forest certification. J. Environ. Manag. 2011, 92, 2984-2992. [CrossRef] [PubMed]

41. Espach, R. When is sustainable forestry sustainable? The Forest Stewardship Council in Argentina and Brazil. Global Environ. Polit. 2006, 6, 55-84. [CrossRef]

42. Nebel, G.; Quevedo, L.; Jacobsen, J.L.; Helles, F. Development and economic significance of forest certification: the case of FSC in Bolivia. For. Policy Econ. 2005, 7, 175-186. [CrossRef]

43. Trishkin, M.; Karjalainen, T.; Lopatin, E. Assessing the attitudes of forest industry companies operating in North-Western Russia towards forest certification. Eur. Sci. J. 2013, 9, 17-34.

44. Palaghianu, C.; Nichiforel, L. Între percepții și precepte în dialogul despre pădurile României. Bucovina Forestieră 2016, 16, 3-8. [CrossRef]

(C) 2018 by the authors. Licensee MDPI, Basel, Switzerland. This article is an open access article distributed under the terms and conditions of the Creative Commons Attribution (CC BY) license (http:// creativecommons.org/licenses/by/4.0/). 